\title{
Effects of Season of Burning on the Microenvironment of Fescue Prairie in Central Saskatchewan
}

\author{
O. W. ArChibolD ${ }^{1}$, E. A. RiPley ${ }^{2}$, and L. Delanoy ${ }^{3}$ \\ ${ }^{1}$ Department of Geography, University of Saskatchewan, Saskatoon, Saskatchewan S7N 5A5 Canada \\ ${ }^{2}$ Department of Plant Sciences, University of Saskatchewan, Saskatoon Saskatchewan S7N 5A8 Canada \\ ${ }^{3}$ Meewasin Valley Authority, 403 3rd Avenue South, Saskatoon, Saskatchewan S7K 3G5 Canada
}

Archibold, O. W., E. A. Ripley, and L. Delanoy. 2003. Effects of season of burning on the microenvironment of fescue prairie in central Saskatchewan. Canadian Field-Naturalist 117(2): 257-266.

The microenvironmental effects of spring, summer and autumn burns were investigated for a small area of fescue prairie in Saskatchewan over two growing seasons. Maximum fire temperature in all burns exceeded $300^{\circ} \mathrm{C}$ at a height of $5-10 \mathrm{~cm}$ in the canopy. At a depth of $1 \mathrm{~cm}$ in the soil, temperature increased to $40^{\circ} \mathrm{C}$ during the summer burn, but was unaffected by burns at other seasons. Spring-burned grasses recovered to the same height as the unburned control plot by the end of the first summer. Grass height was similar in all plots by the end of the second growing season, but aboveground biomass in all burned plots was about half that of the control. Graminoid leaf area index at the end of the second growing season ranged from 0.65 in the control plot to 0.27 in the autumn burn. Surface albedos dropped to about 0.03 immediately after burning and took about 3 months to return to the pre-burn values near 0.20. By mid-June of the second year, albedos were similar in all plots. Soil temperatures at $50 \mathrm{~cm}$ depth in the burned plots were higher than in the control during the first summer and lower during the winter. The greatest winter snowpack ( $73 \mathrm{~mm}$ water equivalent) accumulated in the control, compared to 48,35 and $25 \mathrm{~mm}$ in the spring, summer and autumn burned plots, respectively. In the first growing season the greatest demand for water occurred in the spring plot followed by the summer, control and autumn plots. In the second season water demand did not differ significantly among plots, reflecting the similarities in plant cover. The microenvironmental effects of a single burning episode in fescue prairie disappear rather quickly, so that there is little long-term impact on the vegetation.

Key Words: Plains Rough Fescue, Festuca altaica subspecies hallii, albedo, fire, microclimate, snow cover, soil temperature, soil moisture, Saskatchewan.

Fire is an important natural element in prairie environments of North America. Originally there were few firebreaks to stop its progress and native species are well adapted to periodic burning (Daubenmire 1968; Vogl 1974). Although natural fires have become less common, prescribed burning is used to improve forage quality through recycling nutrients, to decrease litter accumulation and to eliminate weeds and woody vegetation. Because water loss typically increases after burning (Anderson 1965), prescribed burns are not recommended in the northern Great Plains during periods of drought (Engle and Bultsma 1984; White and Currie 1983). There is an extensive literature on the ecological effects of grassland fires and species response to fire frequency, fire intensity and time of burning (see for example: Anderson et al. 1970; Ewing and Engle 1988; Redmann et al. 1993; Romo et al. 1993). The extent and frequency of burning has declined with the spread of agriculture across the Canadian prairies (Raby 1966). This has led to the invasion of woody species and the build-up of large amounts of standing dead vegetation and thatch, creating a fire hazard to adjacent agricultural land. To counteract these trends, prescribed burning was introduced in the northern Great Plains and many studies have been undertaken to establish the optimum frequency and timing of burning (Romo et al. 1993; Steuter 1987; White and Currie 1983; Wright and Bailey 1980; Vogl 1974).
Grassland fires subject aboveground plant parts to temperatures as high as $600^{\circ} \mathrm{C}$ (Bailey and Anderson 1980; Archibold et al. 1998), killing most plant tissue and exposing the soil surface. Species growing actively when the area is burned are more susceptible to injury than dormant species or those just initiating growth (Anderson et al. 1970). The fire front passes quickly across the fine fuel so there is little heat penetration into the soil; temperatures immediately below the surface rarely exceed $50^{\circ} \mathrm{C}$ (Tester 1965). Soils exposed by early season burning warm more rapidly than in unburned areas and growth typically begins earlier in the spring. This can increase water demand. Conversely, late season fires allow the exposed soil to cool more rapidly in autumn (Peet et al. 1975). However, few studies have measured how burning affects the microenvironment of temperate grasslands. When a vegetation canopy is removed by fire, the surface energy balance is changed (Bremer and Ham 1999) which leads to modifications in the aboveground and belowground microclimates (Ewing and Engle 1988; Old 1969). There are several reasons for this: aerodynamic changes occur as the wind penetrates closer to the surface, transporting heat and water vapour more rapidly than before; the surface albedo diminishes due to the exposure of soil (Bowers and Hanks 1965) and the deposition of burnt organic material; and the removal of most transpiring leaves limits moisture loss to direct 
soil evaporation. The immediate result is that more solar energy is absorbed at the soil surface, increasing soil evaporation and daytime heat flow into the soil and atmosphere. The lack of an insulating cover of vegetation allows heat to be radiated away more rapidly at night. The effects of burning in one year therefore can affect plant growth in subsequent years, especially in regions where precipitation is quite variable.

The present study compares the microenvironments of unburned fescue prairie in plots burned in spring, summer and autumn of 1998. The effect of time of burn on vegetation regrowth was monitored over two growing seasons together with the impact of seasonal fires on the microenvironment of the burned plots. This study provides an assessment of the effects of season of burning on the prairie microenvironment with a view to predicting differences in vegetation growth and water use. This information will assist explaining time-of-burning impacts on species growth and composition and provide a better understanding of the use of fire as a management tool in fescue prairie grassland. The paucity of previous studies in this area may reflect the difficulties involved in setting up such an experiment, which also constrained the present study to a single plot for each treatment.

\section{Study area}

Prescribed burning was carried out at Kernen Prairie, a remnant fescue prairie stand near Saskatoon, Saskatchewan $\left(52^{\circ} 11^{\prime} \mathrm{N}, 106^{\circ} 42^{\prime} \mathrm{W}\right)$, during the 1998 growing season; the selected area had last been burned in May 1991. As described by Pylypec (1986) the dominant grass at the site is Plains Rough Fescue (Festuca altaica subsp. hallii) which grows in association with Kentucky Bluegrass (Poa pratensis) and sedges (Carex heliophila, C. obtusata). Several forbs including asters (Aster falcatus, A. laevis), Northern Bedstraw (Galium boreale), Three-flowered Avens (Geum triflorum) and Prairie Sage (Artemisia ludoviciana) are also present together with the low growing shrub Western Snowberry (Symphoricarpos occidentalis) and roses (Rosa spp.) (Pylypec 1986). Soils in this area are fine-textured chernozems derived from glacio-lacustrine clays; they have a surface dry bulk density of $1.33 \mathrm{~g} \mathrm{~cm}^{-3}$.

The region experiences a continental climate with mean monthly temperatures ranging from $-18^{\circ} \mathrm{C}$ in January to $19^{\circ} \mathrm{C}$ in July; average annual precipitation is $360 \mathrm{~mm}$, of which about $30 \%$ falls as snow (Atmospheric Environment Service 1993). During the growing season mean monthly temperatures increase from $11^{\circ} \mathrm{C}$ in May to $19^{\circ} \mathrm{C}$ in July and drop to $11^{\circ} \mathrm{C}$ by September. In 1998 temperatures averaged $2-3^{\circ} \mathrm{C}$ above normal in May, $1-2^{\circ} \mathrm{C}$ below normal in June and near normal in July, with warmer than normal conditions prevailing until the end of the year (Atmospheric Environment Service 1998, 1999). In 1999 temperatures averaged $1-2^{\circ} \mathrm{C}$ below normal except for near normal conditions in August. Monthly precipita- tion normally averages about $20 \mathrm{~mm}$ during the winter months, rising in the spring to a peak of $60 \mathrm{~mm}$ in June and July, and returning to winter values by October. In 1998 precipitation was light early in the growing season, then near normal except for a rainy August; the April to September total averaged 5\% above normal. In contrast, 1999 was considerably wetter, except for August and September, with 17\% above normal precipitation during April to September (Figure 1).

\section{Methods}

Four contiguous $10 \times 10 \mathrm{~m}$ plots were established in April 1998. One was maintained as a control and the remaining plots were burned in the spring (6 May 1998), summer (26 June 1998) and autumn (8 October 1998), respectively. Instruments were installed in all plots to measure reflected solar radiation (Li-Cor LI-200SZ pyranometer), soil temperatures at 2, 10 and $50 \mathrm{~cm}$ (Campbell Scientific Model 107 thermistor temperature probe) and soil water content of the 0-30 cm layer (Campbell Scientific CS615 TDR - time domain reflectometry - probe). Unfortunately, animals frequently damaged the instrument cables, so some of the data for the $2 \mathrm{~cm}$ soil temperatures, TDR and solar radiation are missing. Incoming solar radiation and precipitation (Campbell Scientific Model TE525 tipping-bucket rain gauge) were measured at a single point in the control plot. The microclimate data were recorded (Campbell Scientific CR10) from 12 May 1998 until 19 October 1999. Snow depth and water equivalent of the snow pack were measured at 30 points in each plot in February 1999, which is usually the month of maximum snow cover in Saskatchewan. Soil water content was measured by neutron probe every 2-4 weeks in each plot to a depth of $100 \mathrm{~cm}$.

Fuel load and moisture content were determined from samples collected at $120.25 \times 0.50 \mathrm{~m}$ quadrats within the prescribed plot prior to each burn. All aboveground vegetation was cut and bagged. The samples were sorted into live and standing dead graminoids, forbs, shrubs and litter, weighed to establish biomass, dried in an oven at $90^{\circ} \mathrm{C}$ and re-weighed. Additional samples, processed in the same manner, were used to determine changes in live and standing dead biomass and litter within the control and treatment plots during each year of the study.

Fire temperatures were measured during each burn at $1 \mathrm{~cm}$ depth in the soil and at heights of 5, 10, 20, 50 and $100 \mathrm{~cm}$ above ground. Four replicate chromelalumel thermocouples were used at each position. The temperatures were recorded every 10 seconds using Campbell CR10 dataloggers. Burning was carried out after establishing a firebreak around the selected plot, and a ring fire was then set to burn towards the temperature probes.

The fescue community is associated with lower topographic positions within Kernen Prairie (Baines 1973) and the sample area was selected because of 


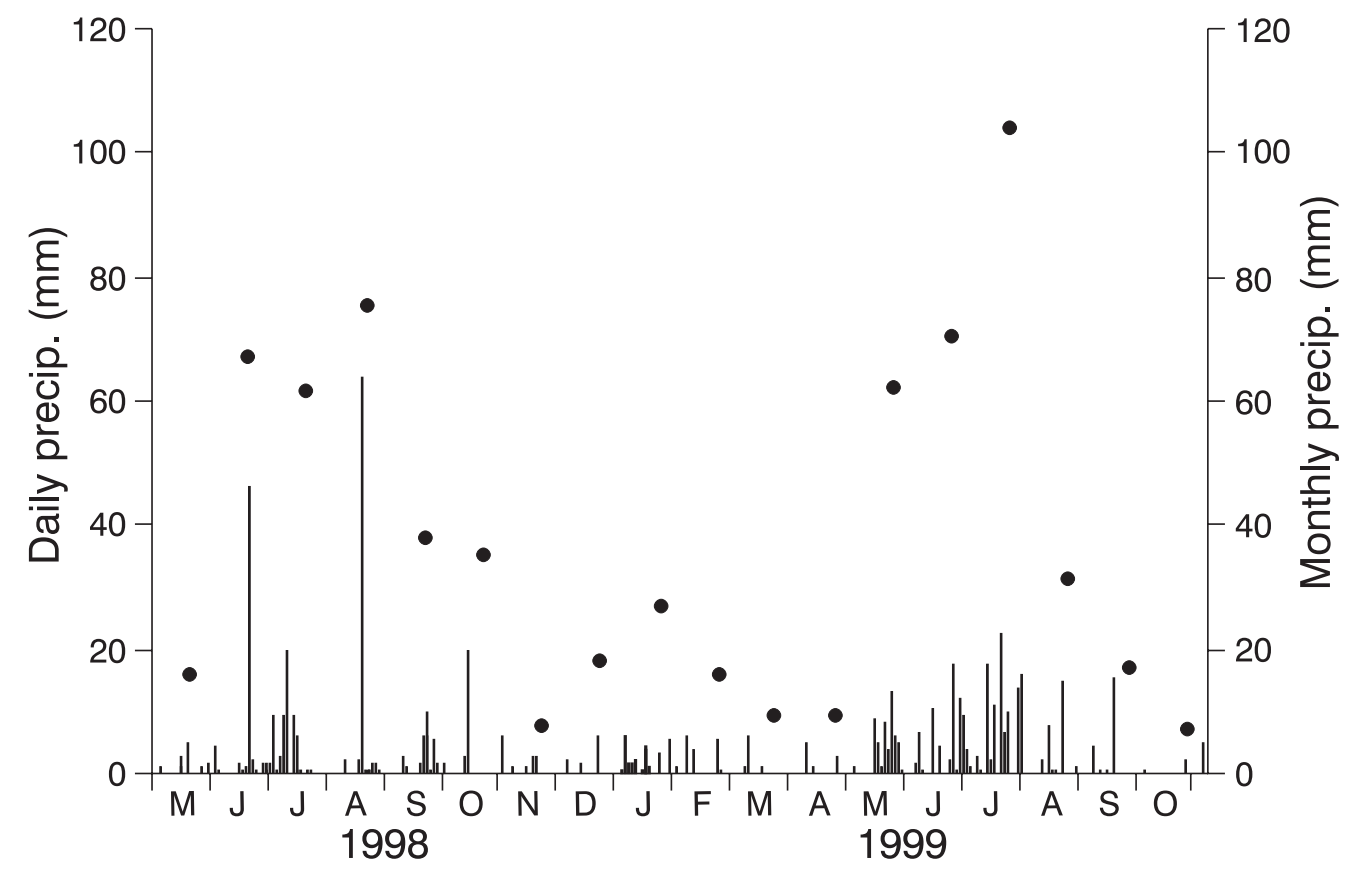

FIGURE 1. Daily (bars) and monthly (dots) precipitation at the study site.

uniformity of the pre-burn plant cover, soil conditions and topography. A vegetation survey of the control and burned plots was carried out at the end of the second growing season. Species composition was measured at each plot using twelve $0.5 \times 0.5 \mathrm{~m}$ quadrats set out in three parallel transects. Density (stems $\mathrm{m}^{-2}$ ) was an appropriate measure for the forbs and shrubs, because of their discrete growth habits and comparatively small populations. Percent cover was used for graminoids because of the difficulty of distinguishing individual plants. Leaf area index (LAI) was determined for graminoids, forbs and shrubs collected from eight $0.25 \times 0.50 \mathrm{~m}$ quadrats in each of the treatment plots and control. The samples were processed using a LiCor LI-3100 Area Meter.

\section{Results and Discussion}

(a) Fire temperatures - The average fuel load in the spring was $0.67 \mathrm{~kg} \mathrm{~m}^{-2}$; this had increased to $0.74 \mathrm{~kg} \mathrm{~m}^{-2}$ by summer and reached $0.75 \mathrm{~kg} \mathrm{~m}^{-2}$ in the autumn (Table 1). These fuel loads are about double those reported by Redmann et al. (1993) and Archibold et al. (1998) in similar stands. Moisture content of the combined live and dead fuel load averaged $12.7 \%$ and $14.6 \%$ at the time of the spring and summer burns, respectively, but increased to $64.5 \%$ prior to the autumn burn. Archibold et al. (1998) previously reported a spring moisture content of $44 \%$ for fescue prairie. Air temperature at the time of the spring burn was $10^{\circ} \mathrm{C}$, relative humidity was $35 \%$ and wind speed was $3.0 \mathrm{~m} \mathrm{~s}^{-1}$. The mean maximum fire temperature observed during the spring burn was $336^{\circ} \mathrm{C}$ at a height of $10 \mathrm{~cm}$ (Table 2). Fire temperatures declined progressively above this height, dropping to $89^{\circ} \mathrm{C}$ at $100 \mathrm{~cm}$ (Figure 2). The mean maximum fire temperature at $5 \mathrm{~cm}$ was $227^{\circ} \mathrm{C}$ and remained above $50^{\circ} \mathrm{C}$, a temperature generally recognized as lethal to plant tissue (Martin et al. 1969), for over $5 \mathrm{~min}$. Soil temperatures at $1 \mathrm{~cm}$ showed no measurable increase during the fire. During the summer burn air temperature was $26^{\circ} \mathrm{C}$, relative humidity was $50 \%$ and wind speed was $4.0 \mathrm{~m} \mathrm{~s}^{-1}$. The highest mean maximum fire temperature was

TABLE 1. Mean ( \pm SD) fuel loads of live and dead material and fuel moisture levels prior to the spring, summer and autumn burns $(\mathrm{n}=12)$.

\begin{tabular}{lccc}
\hline \hline & Spring & Summer & Autumn \\
\hline Fuel load $\left(\mathrm{g} \mathrm{m}^{-2}\right)$ & $670.4 \pm 334.4$ & $742.4 \pm 215.8$ & $748.8 \pm 197.6$ \\
Fuel moisture $(\%)$ & $12.7 \pm 1.8$ & $14.6 \pm 3.4$ & $64.5 \pm 17.3$ \\
\hline \hline
\end{tabular}


TABLE 2. Mean maximum fire temperatures $\left({ }^{\circ} \mathrm{C}\right)$ and durations above $50^{\circ} \mathrm{C}$ during the spring, summer and autumn burns.

\begin{tabular}{|c|c|c|c|c|c|c|}
\hline & \multicolumn{2}{|c|}{ Spring } & \multicolumn{2}{|c|}{ Summer } & \multicolumn{2}{|c|}{ Autumn } \\
\hline & $\begin{array}{c}\text { Temperature } \\
\left({ }^{\circ} \mathrm{C}\right)\end{array}$ & $\begin{array}{c}50^{\circ} \mathrm{C} \\
\text { Duration } \\
(\mathrm{min})\end{array}$ & $\begin{array}{c}\text { Temperature } \\
\left({ }^{\circ} \mathrm{C}\right)\end{array}$ & $\begin{array}{c}50^{\circ} \mathrm{C} \\
\text { Duration } \\
(\mathrm{min})\end{array}$ & $\begin{array}{c}\text { Temperature } \\
\left({ }^{\circ} \mathrm{C}\right)\end{array}$ & $\begin{array}{c}50^{\circ} \mathrm{C} \\
\text { Duration } \\
(\min )\end{array}$ \\
\hline $100 \mathrm{~cm}$ & 89 & 1.0 & 156 & 2.7 & 151 & 1.7 \\
\hline $50 \mathrm{~cm}$ & 134 & 1.2 & 209 & 3.5 & 174 & 2.0 \\
\hline $20 \mathrm{~cm}$ & 292 & 2.0 & 269 & 5.0 & 280 & 2.3 \\
\hline $10 \mathrm{~cm}$ & 336 & 3.0 & 290 & 5.7 & 316 & 2.7 \\
\hline $5 \mathrm{~cm}$ & 227 & 5.2 & 330 & 7.2 & 324 & 3.3 \\
\hline$-1 \mathrm{~cm}$ & 8 & 0 & 44 & 0 & 14 & 0 \\
\hline
\end{tabular}

$330^{\circ} \mathrm{C}$ at $5 \mathrm{~cm}$ and remained above $50^{\circ} \mathrm{C}$ for more than $7 \mathrm{~min}$; corresponding values at $100 \mathrm{~cm}$ were $156^{\circ} \mathrm{C}$ and $2.7 \mathrm{~min}$ above $50^{\circ} \mathrm{C}$. A combination of greater thatch accumulation and drier soil conditions probably contributed to the high soil temperature recorded during this fire. Air temperature was $20^{\circ} \mathrm{C}$, humidity $40 \%$ and wind speed $2.5 \mathrm{~m} \mathrm{~s}^{-1}$ during the autumn burn. The highest mean maximum fire temperature was $324^{\circ} \mathrm{C}$ at $5 \mathrm{~cm}$ and dropped to $151^{\circ} \mathrm{C}$ at $100 \mathrm{~cm}$; the longest duration for temperatures above $50^{\circ} \mathrm{C}$ was 3.3 minutes at $5 \mathrm{~cm}$. Soil temperatures did not increase during the autumn burn. Fire temperatures in all burns were generally lower than reported by Archibold et al. (1998) for fescue, but are comparable to grassland fires reported by Bailey and Anderson (1980).

(b) Vegetation - A total of 20 species of forbs was recorded at the study site at the end of the second growing season (Table 3). White Prairie Aster was the most abundant species with densities ranging from 69 stems $\mathrm{m}^{-2}$ in the spring plot to 139 stems $\mathrm{m}^{-2}$ in the summer plot. Prairie Sage, Northern Bedstraw and Woolly Yarrow (Achillea millefolium) were also found in all plots. Three species, Harebell (Campanula rotundifolia), Field Chickweed (Cerastium arvense) and Bladder Campion (Silene cucubalis) were present only in the control plot. Late Yellow Locoweed (Oxytropis campestris) occurred only in the summer plot while Prairie Crocus (Anemone patens) and American Vetch (Vicia americana) were found only in the autumn plot. The restriction of species to a treatment plot likely reflects its comparative rarity at the site rather than a consequence of the fire. Shrubs, represented by rose and Western Snowberry, were ubiquitous, the latter being most abundant. Grass cover ranged from $12.2 \%$ in the summer plot to $25.5 \%$ in the control. Nine grass species were recorded; Plains Rough Fescue was the most abundant grass with Kentucky Bluegrass and Western Porcupine Grass (Stipa spartea var. curtiseta) also important. Three sedge species also contributed to the vegetation cover. The spring plot had a higher density of rose and a lower density of Western Snowberry than the other plots; some herbaceous species, such as White Cinquefoil (Potentilla arguta) and
Stiff Goldenrod (Solidago rigida), also were better represented.

During the first growing season the average height of the grass canopy in the control reached a maximum of $28 \mathrm{~cm}$ and increased to $50 \mathrm{~cm}$ by the end of the second growing season (Figure 3) with panicles of the grasses extending to an average height of $70 \mathrm{~cm}$. The spring plot greened up quickly but growth was not prolific. By the end of the first season the vegetative canopy reached $26 \mathrm{~cm}$. A small increase occurred in the second season $(27 \mathrm{~cm})$ with panicles forming a very diffuse layer at an average height of $59 \mathrm{~cm}$. Toynbee (1987) also has reported a reduction in flowering in fescue following spring burning. Growth was slower in the summer plot and at the end of the second season averaged $20 \mathrm{~cm}$, although panicles projected above the leaf canopy to $73 \mathrm{~cm}$. Air temperature dropped to near freezing soon after the autumn burn and plant growth ceased. This plot went through winter in a blackened state, and in the following growing season the grasses reached a mean height of $22 \mathrm{~cm}$ with panicles projecting to $60 \mathrm{~cm}$. The grasses in the control plot were significantly $(\mathrm{P} \leq 0.01)$ taller than in any treatment plot, and grass height in the spring and autumn burns was also significantly different. Mean shrub height in the control at the end of the second growing season was approximately $40 \mathrm{~cm}$. At this time the shrub cover in the spring burn averaged $25 \mathrm{~cm}$ compared to $29 \mathrm{~cm}$ in the summer burn and $33 \mathrm{~cm}$ in the autumn burn. Shrub height in the control was significantly taller $(\mathrm{P} \leq 0.01)$ than in all treatment plots; no significant differences were detected between treatments.

Live biomass in the control in May 1998 averaged $0.58 \mathrm{~kg} \mathrm{~m}^{-2}$ (Figure 4). By June this had increased to $0.75 \mathrm{~kg} \mathrm{~m}^{-2}$ and in September reached $0.76 \mathrm{~kg} \mathrm{~m}^{-2}$. This compares to the September biomass of $0.27 \mathrm{~kg} \mathrm{~m}^{-2}$ in the spring burn. Regrowth in the summer burn commenced quickly after the fire; within one month the biomass totaled $0.09 \mathrm{~kg} \mathrm{~m}^{-2}$ and increased to $0.18 \mathrm{~kg} \mathrm{~m}^{-2}$ by September 1998. The autumn burn did not green up until the following spring. In 1999 plant growth in the control was less prolific than in 1998 and at the end of season biomass was $0.64 \mathrm{~g} \mathrm{~m}^{-2}$. In all treatments 

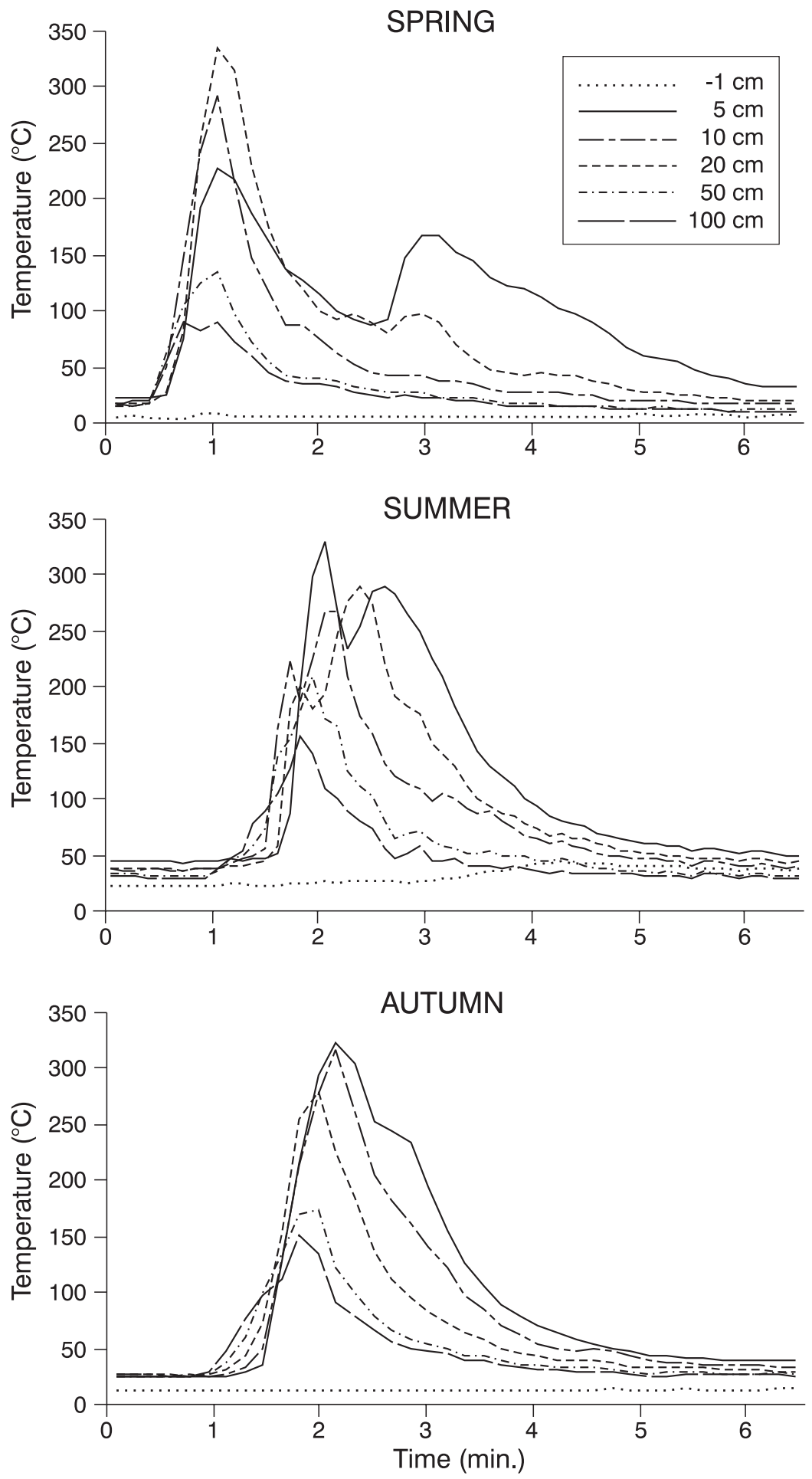

FIGURE 2. Mean fire temperatures at the soil surface and at five heights above ground during the spring, summer and autumn burns. 
TABLE 3. Density of forbs and shrubs (stems $\mathrm{m}^{-2}$ ) and cover of graminoids (\%) in the control and burned plots at the end of the second growing season.

\begin{tabular}{|c|c|c|c|c|}
\hline & Control & Spring & Summer & Autumn \\
\hline \multicolumn{5}{|l|}{ Forbs } \\
\hline Achillea millefolium & 2.7 & 8.3 & 1.7 & 8.3 \\
\hline Androsace septentrionalis & 0.7 & 5.7 & 14.0 & \\
\hline Anemone patens & & & & 1.3 \\
\hline Artemisia frigida & 3.7 & 2.3 & 1.7 & 2.7 \\
\hline Artemisia ludoviciana & 23.7 & 9.7 & 3.3 & 20.3 \\
\hline Aster falcatus & 91.7 & 69.3 & 138.7 & 99.3 \\
\hline Aster laevis & 1.3 & 7.3 & 10.3 & \\
\hline Astragalus goniatus & & 2.3 & & 13.7 \\
\hline Campanula rotundifolia & 2.0 & & & \\
\hline Cerastium arvense & 0.7 & & & \\
\hline Galium boreale & 13.0 & 8.3 & 5.0 & 17.0 \\
\hline Geum triflorum & 0.7 & 9.3 & 11.7 & \\
\hline Oxytropis campestris & & & 14.3 & \\
\hline Phlox hoodii & 1.7 & 1.3 & 0.7 & 0.7 \\
\hline Potentilla arguta & & 4.7 & 1.7 & 0.7 \\
\hline Silene cucubalis & 0.3 & & & \\
\hline Solidago missouriensis & 0.3 & 0.3 & 11.0 & \\
\hline Solidago rigida & & 6.0 & 0.3 & \\
\hline Vicia americana & 0.3 & & & 0.7 \\
\hline Viola adunca & 0.0 & 2.7 & 2.0 & \\
\hline \multicolumn{5}{|l|}{ Shrubs } \\
\hline Rosa spp. & 4.3 & 17.3 & 1.0 & 1.7 \\
\hline Symphoricarpos occidentalis & 37.3 & 28.7 & 42.3 & 35.7 \\
\hline \multicolumn{5}{|l|}{ Grasses } \\
\hline Agropyron dasystachum & 0.1 & & 0.1 & 0.1 \\
\hline Agropyron smithii & & & 0.1 & 0.2 \\
\hline Agropyron subsecundum & 1.3 & 0.5 & 0.1 & 0.3 \\
\hline Festuca altaica & 11.3 & 13.2 & 7.0 & 8.8 \\
\hline Helictotrichon hookeri & & & & 0.1 \\
\hline Koeleria cristata & & 0.2 & & 0.1 \\
\hline Poa pratensis & 6.8 & 0.2 & 1.3 & 5.4 \\
\hline Stipa spartea & 5.6 & 4.9 & 3.0 & 2.2 \\
\hline Stipa viridula & 0.5 & 0.2 & 0.7 & 1.5 \\
\hline \multicolumn{5}{|l|}{ Sedges } \\
\hline Carex eleocharis & 0.4 & 0.1 & 0.3 & 0.7 \\
\hline Carex obtusata & 1.0 & 1.0 & & \\
\hline Carex heliophila & 1.4 & 2.6 & 3.2 & 3.7 \\
\hline
\end{tabular}

plant biomass in 1999 exceeded that of the previous year; a similar pattern of was noted by Redmann et al. (1993) with full recovery usually occurring in the third post-fire season. (Clarke et al. 1943; Dix 1960). The contribution of graminoids to end of season biomass was highest in the control plot and decreased progressively in the spring, summer and autumn burns (Table 4). Significant differences in grass biomass were noted between the control and the summer and autumn plots $(\mathrm{P} \leq 0.05, \mathrm{df}=12)$. In contrast, forb biomass was low-

TABLE 4. Mean biomass $\left(\mathrm{g} \mathrm{m}^{-2} \pm \mathrm{SD}\right)$ for grasses, forbs and shrubs in the spring, summer and autumn burns at the end of the second growing season.

\begin{tabular}{lcccc}
\hline \hline & Control & Spring & Summer & Autumn \\
\hline Grasses & $0.40 \pm 0.09^{\mathrm{a}^{*}}$ & $0.26 \pm 0.03^{\mathrm{ab}}$ & $0.17 \pm 0.03^{\mathrm{b}}$ & $0.17 \pm 0.05^{\mathrm{b}}$ \\
Forbs & $0.06 \pm 0.01^{\mathrm{a}}$ & $0.14 \pm 0.03^{\mathrm{a}}$ & $0.11 \pm 0.02^{\mathrm{a}}$ & $0.08 \pm 0.04^{\mathrm{a}}$ \\
Shrubs & $0.18 \pm 0.04^{\mathrm{a}}$ & $0.03 \pm 0.01^{\mathrm{ab}}$ & $0.09 \pm 0.02^{\mathrm{ab}}$ & $0.31 \pm 0.07^{\mathrm{b}}$ \\
\hline
\end{tabular}

\footnotetext{
*Values in the same row with the same letter are not significantly different $(\mathrm{P} \leq 0.05)$
} 


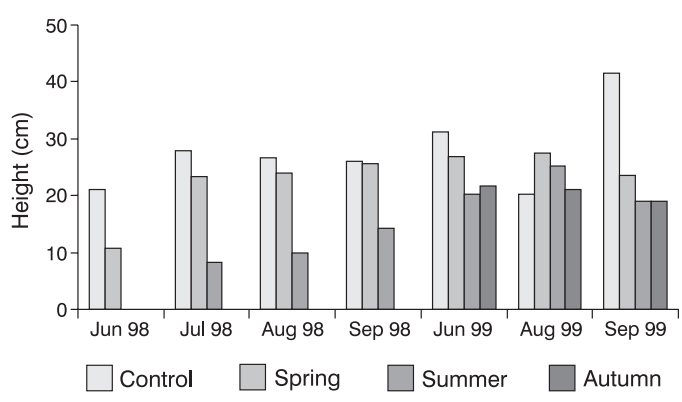

FIGURE 3. Mean vegetation height in the control and spring, summer and autumn burns at selected times during the 1998 and 1999 growing seasons.

est in the control plot and highest in the spring burn, although interplot differences were not significant. Shrub biomass was greatest in the autumn burn with significant differences in biomass noted between the autumn plot and the spring and summer plots. The thatch layer in the control plot was approximately $10 \mathrm{~cm}$ deep at the end of the second growing season, but no appreciable depth of litter had accumulated in any of the burned plots. Litter biomass in the control plot was $0.11 \mathrm{~kg} \mathrm{~m}^{-2}$ compared to $0.01 \mathrm{~kg} \mathrm{~m}^{-2}$ in the spring; litter was negligible in the summer and autumn plots. Litter accumulates slowly in burned prairie (Dix 1960) and the paucity of litter is considered to be one of the longest lasting impacts of fire (Redmann et al. 1993).

LAI for graminoids was 0.64 in the control which was significantly higher than the LAI in the summer and autumn plots (Table 5). Forb LAI declined with lateness of burn, although all treatments exceeded the value for the control. Conversely, for shrubs LAI increased with lateness of the burn and ranged from 0.04 in the spring plot to 0.50 in the autumn plot; significant differences were noted between the autumn plot and the spring and summer plots.

(c) Microclimate - Surface albedos, calculated as the ratio of daily totals of reflected and incoming solar radiation, averaged approximately $20 \%$ during the snow-free period (Figure 5). All three burns dropped the albedo to about $3 \%$, which in the spring and summer plots took about 2 months to recover to pre-burn values. This decrease in albedo is greater than reported in other studies. For example, Knapp (1984) reported

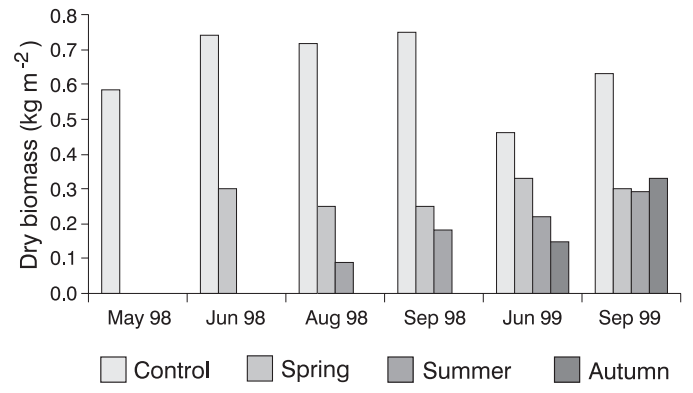

FIGURE 4. Total biomass in the control and spring, summer and autumn burns at selected times during the 1998 and 1999 growing seasons.

a drop from $18 \%$ to $10 \%$ ten days following burning in the tallgrass prairie of Kansas. The change in albedo caused by the autumn burn was obscured by a heavy snowfall a few days later; after the snow melted, the albedo was about 5\% and remained at this value until the arrival of the permanent winter snowpack at the beginning of December. The winter albedo reached about $90 \%$ in early January when most of the vegetation was covered with snow. This dropped as the snowpack aged and was about $70 \%$ just prior to snowmelt in late February. By mid-May 1999 values ranged from $12 \%$ for the autumn burn to $15 \%$ for the summer burn and $18 \%$ for the spring burn and control. By mid-June the albedos of all plots were similar.

In the first growing season the maximum $2 \mathrm{~cm}$ soil temperature in the control was $23^{\circ} \mathrm{C}$ compared to $31^{\circ} \mathrm{C}$ in the summer plot shortly after it was burned. The $2 \mathrm{~cm}$ soil temperature in the autumn plot was unaffected because the surface was covered with snow following the fire, but over winter dropped to $-19^{\circ} \mathrm{C}$ compared to $-16^{\circ} \mathrm{C}$ in the summer plot and $-10^{\circ} \mathrm{C}$ in the control. In the second growing season the surface soils in the summer and autumn plots warmed faster than the control. By mid-summer the maximum $2 \mathrm{~cm}$ temperatures recorded in the treatment plots were all similar at $26-27^{\circ} \mathrm{C}$ compared to $21^{\circ} \mathrm{C}$ in the control plot.

Soil temperatures at $10 \mathrm{~cm}$ in the spring and summer plots increased in the months following burning (Figure 6) and remained about $2^{\circ} \mathrm{C}$ higher than the control through the summer. By October the $10 \mathrm{~cm}$ soil temperatures in all plots were similar, but by mid winter the burned plots were approximately $2^{\circ} \mathrm{C}$ cooler

TABLE 5. Mean LAI ( \pm SD) for grasses, forbs and shrubs in the spring, summer and autumn burns at the end of the 1999 growing season $\left(\mathrm{cm}^{2} \mathrm{~cm}^{-2}\right)$.

\begin{tabular}{lcccc}
\hline \hline & Control & Spring & Summer & Autumn \\
\hline Grasses & $0.64 \pm 0.14^{\mathrm{a}^{*}}$ & $0.41 \pm 0.04^{\mathrm{ab}}$ & $0.28 \pm 0.04^{\mathrm{b}}$ & $0.27 \pm 0.07^{\mathrm{b}}$ \\
Forbs & $0.09 \pm 0.02^{\mathrm{a}}$ & $0.23 \pm 0.05^{\mathrm{a}}$ & $0.18 \pm 0.02^{\mathrm{a}}$ & $0.13 \pm 0.06^{\mathrm{a}}$ \\
Shrubs & $0.27 \pm 0.06^{\mathrm{a}}$ & $0.04 \pm 0.02^{\mathrm{ab}}$ & $0.15 \pm 0.03^{\mathrm{ab}}$ & $0.50 \pm 0.11^{\mathrm{b}}$ \\
\hline \hline
\end{tabular}

*Values in the same row with the same letter are not significantly different $(\mathrm{P} \leq 0.05)$ 


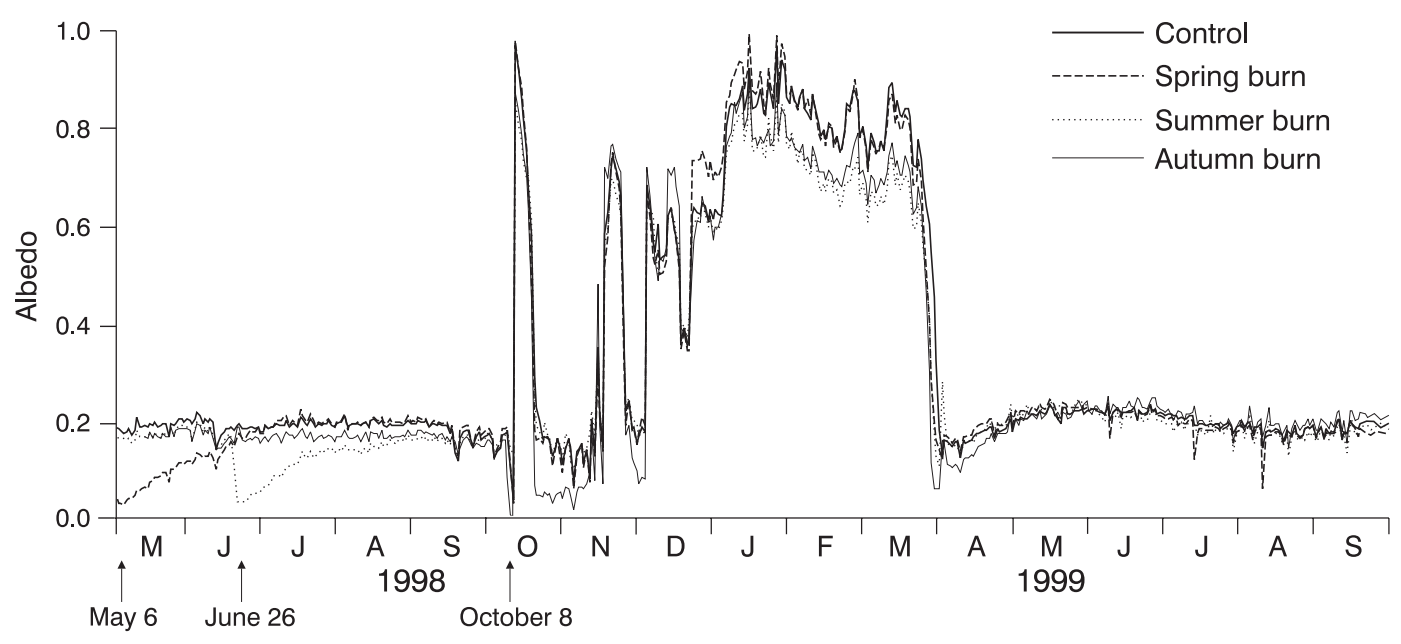

FIGURE 5. Daily albedos in the control and spring, summer and autumn burns.

than the control. In the second growing season the $10 \mathrm{~cm}$ soil temperatures in the spring and summer plots were about $1.5^{\circ} \mathrm{C}$ warmer than the control; in comparison the autumn plot was about $2.5^{\circ} \mathrm{C}$ warmer with the mean temperature in August reaching $18.6^{\circ} \mathrm{C}$. This is similar to the $3^{\circ} \mathrm{C}$ increase in burned tallgrass
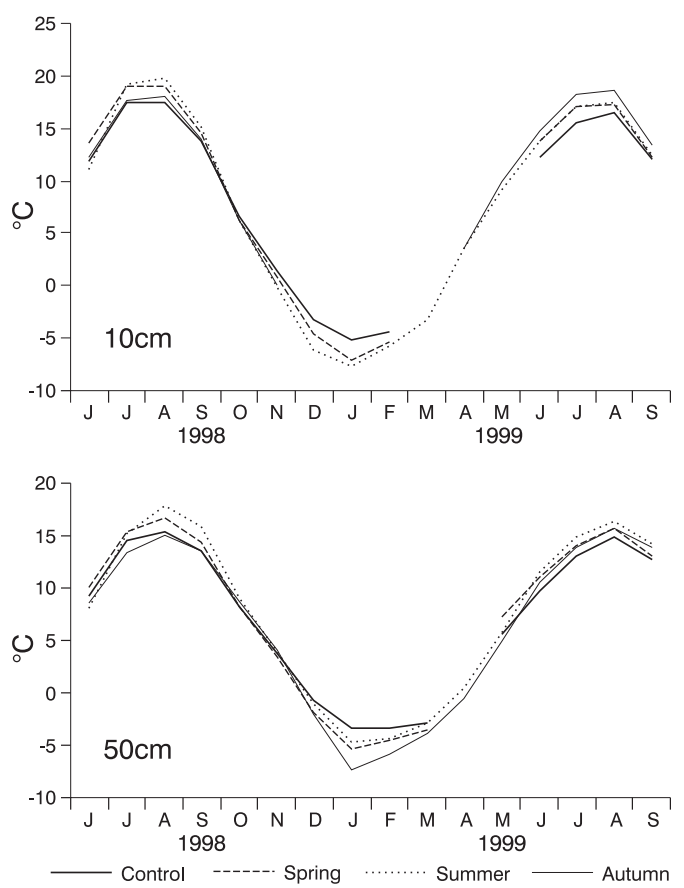

FIGURE 6. Mean monthly soil temperatures at $10 \mathrm{~cm}$ and $50 \mathrm{~cm}$ in the control and spring, summer and autumn burns. prairie reported by Rice and Parenti (1978). In the first growing season mean monthly soil temperatures at $50 \mathrm{~cm}$ increased to a maximum of $17.9^{\circ} \mathrm{C}$ in the summer plot in August compared to maximum values of $15.4^{\circ} \mathrm{C}$ in the control and $15.1^{\circ} \mathrm{C}$ and $16.7^{\circ} \mathrm{C}$, respectively, for the autumn and spring burns (Figure 6). By mid-winter the mean $50 \mathrm{~cm}$ soil temperature in the autumn burn had dropped to $-7.3^{\circ} \mathrm{C}$, which was about $2.5^{\circ} \mathrm{C}$ colder than the other burned plots and almost $4^{\circ} \mathrm{C}$ colder than the control. Differences in $50 \mathrm{~cm}$ soil temperatures were less marked in the second growing season.

Temperature differences between plots may be attributed to the insulating effect of the litter and snow cover. A mulch of litter helps to reduce loss of both sensible and latent heat as well as radiative heat loss from the soil. Kohnke and Werkhoven (1963) demonstrated that soil temperature at a depth of $10 \mathrm{~cm}$ was the same as that recorded at $2.5 \mathrm{~cm}$ under a straw mulch of $0.38 \mathrm{~kg}$ $\mathrm{m}^{-2}$. Similarly, Unger (1978) reported that winter soil temperatures increased by approximately $0.1^{\circ} \mathrm{C}$ for each $0.1 \mathrm{~kg}$ of straw mulch applied. Snow provides better insulation for strawberry plants than straw mulch under severe winter conditions (Boyce and Linde 1986). The thermal diffusivity of straw is about $5 \times 10^{-6} \mathrm{~m}^{2} \mathrm{~s}^{-1}$ and ranges from $4 \times 10^{-7} \mathrm{~m}^{2} \mathrm{~s}^{-1}$ for fresh snow to over $5 \times 10^{-7} \mathrm{~m}^{2} \mathrm{~s}^{-1}$ for a mature snowpack (List 1966). In addition, solar radiation will penetrate a translucent snowpack and provide a net radiative heat gain (Marchand 1984; Oke 1978). Water vapor also moves upwards from the deep warmer soil towards the colder surface and releases latent heat when it condenses. If snow arrives before freezing occurs, some of this heat is retained within the soil.

At the end of the first growing season, water content was highest in the control and decreased progressively 
TABLE 6. Soil water content $(\mathrm{mm})$ of the control and treatment plots during the 1998 and 1999 growing seasons measured by neutron probe.

\begin{tabular}{lcc}
\hline \hline & 1998 growing season & 1999 growing season \\
\hline Precipitation & 248 & 270 \\
Control & +13 & -9 \\
Spring burn & -17 & -3 \\
Summer burn & -5 & -6 \\
Autumn burn & +29 & -8 \\
\hline \hline
\end{tabular}

in the autumn, spring and summer burns (Figure 7). The drier soils in the spring and summer plots are attributed to a combination of increased soil evaporation due to loss of canopy and mulch and to high water demand from vigorous regrowth; the autumn plot would have lost moisture mainly through transpiration. Moisture levels increased in April as snowmelt percolated into the soil. At this time the greatest moisture reserves occurred in the control and the autumn burn was the driest. This pattern is consistent with observations made by de Jong (1973) and Trlica and Schuster (1969) who reported low soil moisture levels in grasslands that had been burned in the autumn. Such differences can be attributed to lower infiltration rates, reduced winter snow-trapping and to microclimatic effects (McMurphy and Anderson 1965; Redmann 1978). In the present study the mid-February snow cover differed significantly $(\mathrm{P} \leq 0.01)$ between plots with snowpack water equivalents of $73 \mathrm{~mm}, 48 \mathrm{~mm}$, $35 \mathrm{~mm}$, and $25 \mathrm{~mm}$ in the control, spring, summer, and autumn burns, respectively. Trlica and Schuster (1969) found a similar reduction in snow cover in autumn burned grassland because the snow is more easily removed by wind. Neutron probe data (Table 6) to a depth of $1.0 \mathrm{~m}$ indicated that during the summer of 1998 the spring burn lost $265 \mathrm{~mm}$ of water compared to 253 in the summer burn $235 \mathrm{~mm}$ in the control and $219 \mathrm{~mm}$ in the autumn burn. During 1999 the difference in soil water loss was about $275 \mathrm{~mm}$ for all plots



FIGURE 7. Mean monthly Time Domain Reflectometry soil water values in the control and spring, summer and autumn burns. which is $56 \%$ to $71 \%$ of values reported for tallgrass prairie in Oklahoma (Burba and Verma 2001).

Many cool season plants, such as those monitored in this study, grow actively during the spring and summer so are affected directly by burning during these seasons. At all times fire removes part or most of the plant canopy, changing surface albedo and radiation exchange, air flow and snow trapping, soil temperature and plant and soil water loss. These effects disappear rather quickly, however, after a single burning episode so that there is little long-term impact on the vegetation. Repeated burnings are likely to have long-term impacts but this was not investigated in this study.

\section{Acknowledgments}

The authors thank Garth Wruck for assisting with the vegetation surveys, Hong Mei Li for helping with laboratory work and Keith Bigelow for drawing the figures. We also appreciate the co-operation of the Department of Plant Sciences, University of Saskatchewan for allowing access to Kernen Prairie.

\section{Literature Cited}

Anderson, K. L. 1965. Time of burning as it affects soil moisture in an ordinary upland bluestem prairie in the Flint Hills. Journal of Range Management 18: 311-316.

Anderson, K. L., E. F. Smith, and C. E. Owensby. 1970. Burning bluestem range. Journal of Range Management 23: 81-92.

Archibold, O. W., L. J. Nelson, E. A. Ripley, and L. Delanoy. 1998. Fire temperatures in plant communities of the northern mixed prairie. Canadian Field-Naturalist 112: 234-240.

Atmospheric Environment Service. 1993. Canadian Climate Normals 1961-90 - Prairie Provinces. Environment Canada, Minister of Supply and Services Canada, Ottawa, Ontario.

Atmospheric Environment Service. 1998-1999. Monthly Meteorological Summaries - Saskatoon International Airport, Prairie and Northern Region. Environment Canada, Winnipeg, Manitoba.

Bailey, A. W., and M. L. Anderson. 1980. Fire temperatures in grass, shrub and aspen forest communities of central Alberta. Journal of Range Management 33: 37-40.

Baines, G. B. K. 1973. Plant distributions on a Saskatchewan prairie. Vegetatio 28: 99-123.

Bowers, S. A., and R. J. Hanks. 1965. Reflection of radiant energy from soils. Soil Science 100: 130-138.

Boyce, B. R., and A. W. Linde. 1986. A comparison of manmade snow, natural snow and straw mulch for winter protection of strawberry plants. Advances in Strawberry Production 5: 25-27.

Bremer, D. J., and J. M. Ham. 1999. Effect of spring burning on the surface energy balance in a tallgrass prairie. Agricultural and Forest Meteorology 97: 43-54.

Burba, G. R., and S. B. Verma. 2001. Prairie growth, PAR albedo and seasonal distribution of energy fluxes. Agricultural and Forest Meteorology 107: 227-240.

Clarke, S. E., E. W. Tisdale, and N. A. Skoglund. 1943. The effects of climate and grazing practices on short-grass prairie vegetation in southern Alberta and southwestern Saskatchewan. Canada Department of Agriculture Technical Bulletin 46. 
Daubenmire, R. 1968. Ecology of fire in grasslands. Advances in Ecological Research 5: 209-266

De Jong, E. 1973. Soil physics II. Soil water. Matador Project Technical Report 29. University of Saskatchewan, Saskatoon.

De Jong, E., and K. B. Macdonald. 1975. Soil moisture regime under native grassland. Geoderma 14: 207-221.

Dix, R. L. 1960. The effects of burning on mulch structure and species composition of mixed grasslands in western North Dakota. Ecology 41: 49-56.

Engle, D. M., and P. M. Bultsma. 1984. Burning of northern mixed prairie during drought. Journal of Range Management 37: 398-401.

Ewing, A. L., and D. M. Engle. 1988. Effects of late summer fire on tallgrass prairie microclimate and community composition. American Midland Naturalist 120: 212-223.

Knapp, A. K. 1984. Post-burn differences in solar radiation, leaf temperature and water stress influencing production in a lowland tallgrass prairie. American Journal of Botany 71: 220-227.

Kohnke, H., and C. H. Werkhoven. 1963. Soil temperature and soil freezing as affected by an organic mulch. Soil Science Society of America Proceedings 27: 13-17.

List, R. J. 1966. Smithsonian Meteorological Tables. Smithsonian Institute, Washington, D. C.

Marchand, P. J. 1984. Light extinction under a changing snowcover. Carnegie Museum of Natural History, Special Publication 10: 33-37.

Martin, R. E., C. T. Cushwa, and R. L. Miller. 1969. Fire as a physical factor in wildland management. Pages 271288 in Proceedings of the 9th Annual Tall Timbers Fire Ecology Conference.

McMurphy, W. E., and K. L. Anderson. 1965. Burning Flint Hills range. Journal of Range Management 18: 265-269.

Oke, T. R. 1978. Boundary Layer Climates. Methuen, London.

Old, S. M. 1969. Microclimate, fire and plant production in an Illinois prairie. Ecological Monographs 38: 355-383.

Peet, M., R. Anderson, and M. S. Adams. 1975. Effect of fire on big bluestem production. American Midland Naturalist 94: 15-26.

Pylypec, B. 1986. The Kernen Prairie - a relict fescue grassland near Saskatoon, Saskatchewan. Blue Jay 44: 222-231.
Raby, S. 1966. Prairie fires in the northwest. Saskatchewan History 19: 81-99.

Redmann, R. E. 1978. Plant and soil water potentials following fire in a northern mixed grassland. Journal of Range Management 31: 443-445.

Redmann, R. E., J. T. Romo, B. Pylypec, and E. A. Driver. 1993. Impacts of burning on primary productivity of Festuca and Stipa-Agropyron grasslands in central Saskatchewan. American Midland Naturalist 130: 262-273.

Rice, E. L., and R. L. Parenti. 1978. Causes of decreases in productivity in undisturbed tall grass prairie. American Journal of Botany 65: 1091-1097.

Romo, J. T., P. L. Grilz, R. E. Redmann, and E. A. Driver. 1993. Standing crop, biomass allocation patterns and soilplant water relations in Symphoricarpos occidentalis Hook. following autumn or spring burning. American Midland Naturalist 130: 106-115.

Steuter, A. A. 1987. C3/C4 production shift on seasonal burns - northern mixed prairie. Journal of Range Management 40: 27-31.

Tester, J. R. 1965. Effects of a controlled burn on small mammals in a Minnesota oak-savanna. American Midland Naturalist 74: 240-244.

Toynbee, K. 1987. Prolific flowering year for Plains Rough Fescue at Kernen Prairie. Blue Jay 45: 142-143.

Trlica, M. J., and J. L. Schuster. 1969. Effects of fire on grasses of the Texas high plains. Journal of Range Management 22: 329-333.

Unger, P. W. 1978. Straw mulch and sorghum. Agronomy Journal 70: 858-864.

Vogl, R. J. 1974. Effects of fires on grasslands. Pages 139194 in Fire and Ecosystems. Edited by T. T. Kozolowski and C. E. Ahlgren. Academic Press, New York.

White, R. S., and P. O. Currie. 1983. Prescribed burning in the northern Great Plains: Yield and cover responses of 3 forage species in the mixed grass prairie. Journal of Range Management 36: 179-183.

Wright, H. A., and A. W. Bailey. 1980. Fire ecology and prescribed burning in the Great Plains - a research review. U.S. Forest Service General Technical Report INT-77.

Received 17 June 2002

Accepted 8 December 2003 